\title{
Analisis dan Perancangan Software WordNet Bahasa Indonesia dengan Graph Database
}

\author{
Seta M. Pamungkas ${ }^{1, *}$, Muhammad Ainul Yaqin², Kurnia Z. Matondang ${ }^{3}$, Asfilia N. Anggraini ${ }^{4}$, \\ Abd. Charis Fauzan ${ }^{5}$ \\ 1,2,3,4 Jurusan Teknik Informatika, Universitas Islam Negeri Maulana Malik Ibrahim, Indonesia \\ ${ }^{5}$ Program Studi Ilmu Komputer, Universitas Nahdlatul Ulama Blitar, Indonesia \\ 18650043@student.uin-malang.ac.id*; 2yaqinov@ti.uin-malang.ac.id; ${ }^{3} 18650044 @$ student.uin-malang.ac.id; \\ 418650040@ student.uin-malang.ac.id; ${ }^{5}$ abdcharis@unublitar.ac.id \\ * corresponding author
}

INFO ARTIKEL

Sejarah Artikel

Diterima: 21 Desember 2019

Direvisi: 13 April 2020

Diterbitkan: 30 Agustus 2020

Kata Kunci

WordNet

Graph Database

Metode Waterfall

\section{ABSTRAK}

Paper ini bertujuan untuk merancang sebuah WordNet dengan menggunakan database bermetode graph yang akan dirancang dengan tahap awal pengelompokan kata hingga tahap akhir yaitu pengimplementasian dalam bentuk aplikasi siap pakai. Penelitian ini merancang aplikasi WordNet siap pakai yang mengimplementasikan database berbasis graph dengan menggunakan Metode Waterfall yang akan menjadi dasar alur dalam perancangan aplikasi. Uji coba dalam penelitian ini berupa: pemilahan kata, input kata ke dalam database, pemberian relasi antar kata, uji coba setiap kata dengan kata yang lain, dan implementasi database ke dalam sebuah aplikasi yang siap pakai. Pada penelitian ini menghasilkan sebuah rancangan WordNet yang menggunakan Bahasa Indonesia dengan penggunaan database berbasis graph model sebagai tempat penyimpanan data. Rancangan WordNet tersebut lalu diimplementasikan ke dalam sebuah aplikasi yang siap pakai. Data yang digunakan dalam penelitian didapatkan dari KBBI dan Tesaurus yang dapat diakses melalui media online. Data dikumpulkan secara berelasi hingga membentuk relasi Sinonim, Antonim, Imbuhan, dan Kata Dasar. Penelitian ini menggunakan relasi yang spesifik untuk menghubungkan antar node, tetapi tidak menggunakannya untuk pencarian jarak antar node. Penelitian ini menggabungkan hasil dari penelitian perancangan WordNet dan perancangan database dengan metode graph hingga membentuk sebuah aplikasi siap pakai.

\section{PENDAHULUAN}

Bahasa dunia dibagi menjadi dua kelompok: bahasa yang sangat memiliki sumber daya perbendaharaan kata yang melimpah dan bahasa yang kekurangan sumber daya perbendaharaan kata [1]. Karena kurangnya dalam perbendaharaan kata, maka kelompok yang memiliki sumber daya yang kurang akan menyebabkan hasil penelitian yang tidak tepat. Bahasa Indonesia adalah salah satu bahasa yang memiliki sumber daya yang kurang, tetapi memiliki perbendaharaan kata yang banyak. Perbendaharaan kata tersebut dapat direlasikan dengan perancangan WordNet. WordNet adalah sebuah database kamus bahasa Inggris yang pertama kali dikembangkan oleh Princeton University. Sedangkan menurut Miller, WordNet merupakan pangkalan data leksikal elektronik.[2] Sebagai salah satu sumber terpenting dalam linguistik komputasi [3], WordNet dapat dikatakan sebagai kamus berdasarkan prinsip-prinsip psikolinguistik. Seiring dengan perkembangan WordNet, sekarang terdapat berbagai domain WordNet dalam berbagai bahasa. WordNet Domains (WND) adalah sumber data leksikal yang memiliki sinkronisasi secara semi-otomatis 
dengan 170 domain telah terorganisasikan secara hierarkis [4]. Untuk mengurangi terjadinya pengulangan dan golongan kata yang sama, maka domain yang asli dibandingkan dengan yang baru, lalu mengukur kualitas sumber dan anomali pada label WDN asli. Hasil dari penelitian ini menunjukkan bahwa domain yang baru menunjukkan hasil yang lebih unggul [4]. Perkembangan WordNet yang semakin banyak membuat teks dalam bentuk elektronik menjadi sulit untuk mendapatkan informasi yang relevan. Komputer harus merubah bahasa alami menjadi bahasa komputasi. Umumnya, pengguna akan memasukkan query dalam bahasa alami yang biasanya memiliki ketidaktepatan, ketidakjelasan, ambiguitas, dan ketidakpastian [5]. Oleh karena itu, dalam metode WordNet diterapkan hubungan semantik, mengasumsikan bahwa sinonim memiliki polaritas yang sama dan antonim memiliki polaritas yang berbeda [6]. Perbedaan yang paling jelas antara WordNet dan kamus standar adalah bahwa WordNet membagi leksikon menjadi lima kategori: kata benda, kata kerja, kata sifat, kata keterangan, dan kata fungsi [7]. Proses merelasikan setiap kata dirancang menggunakan database yang berbasis graph model. Fleksibilitas graph model memungkinkan kami untuk menambahkan node baru dan hubungan baru tanpa merusak atau memindah data — data asli dan isinya tetap utuh [8]. Selain itu penggunaan graph model dalam database memiliki waktu eksekusi yang relatif flat atau konstan walaupun menghadapi kompleksitas data yang besar. Waktu eksekusi yang relatif konstan tersebut disebabkan karena kemampuan graph yang mempunyai sifat merambat dari satu node ke node yang lain. Sehingga, waktu eksekusi bergantung pada ukuran antar segmen graph [9]. Penelitian ini sebelumnya pernah diteliti oleh Nagi yang merepresentasikan WordNet menggunakan Graph Database dengan tools Neo4j [3]. Penelitian tersebut mendapatkan hasil bahwa waktu eksekusi lebih cepat 20\% [3]. Perancangan WordNet menggunakan bahasa selain bahasa yang memiliki sumber daya berlimpah pernah diteliti oleh Khuyagbaatar dalam penelitiannya yang berjudul "Building The Mongolian WordNet"[1]. Namun, penelitian mereka belum sampai tahap implementasi ke dalam aplikasi siap pakai.

Perancangan WordNet pada penelitian ini akan dirancang menggunakan aplikasi Neo4J. Neo4J sangat cocok digunakan untuk pembangunan WordNet karena waktu eksekusi query yang relatif konstan dan hanya sepersekian detik untuk mengeksekusi query [8]. Uji coba WordNet dilakukan untuk mendapatkan hasil yang maksimal. Uji coba akan berupa mencari dan memvisualisasikan seluruh jarak terdekat antara 2 kata, menampilkan setiap kata yang berelasi dengan kata kunci, dan pencarian kata berdasarkan relasi dengan kata kunci. Pada penelitian ini, uji coba tidak difokuskan terhadap relasi antara node secara spesifik. Hasil perancangan dan uji coba database akan diimplementasikan ke dalam sebuah program yang memuat tentang relasi kata kunci dengan kata lain dan pengertiannya.

\section{METODE}

Perancangan software WordNet berbasis graph database menerapkan Metode Waterfall. Metode Waterfall adalah metode yang mengembangkan sistem melewati tahapan perencanaan, analisis, perancangan, implementasi, dan pemeliharaan sebagaimana Gambar 1. Metode ini sangat baik untuk digunakan jika persyaratannya telah dipahami dengan baik.

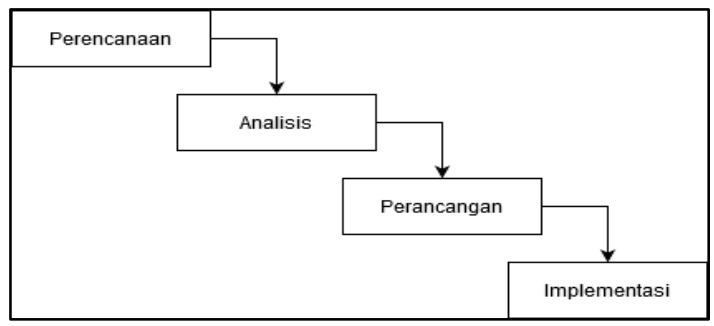

Gambar 1. Metode dalam pengembangan software 


\section{Perencanaan}

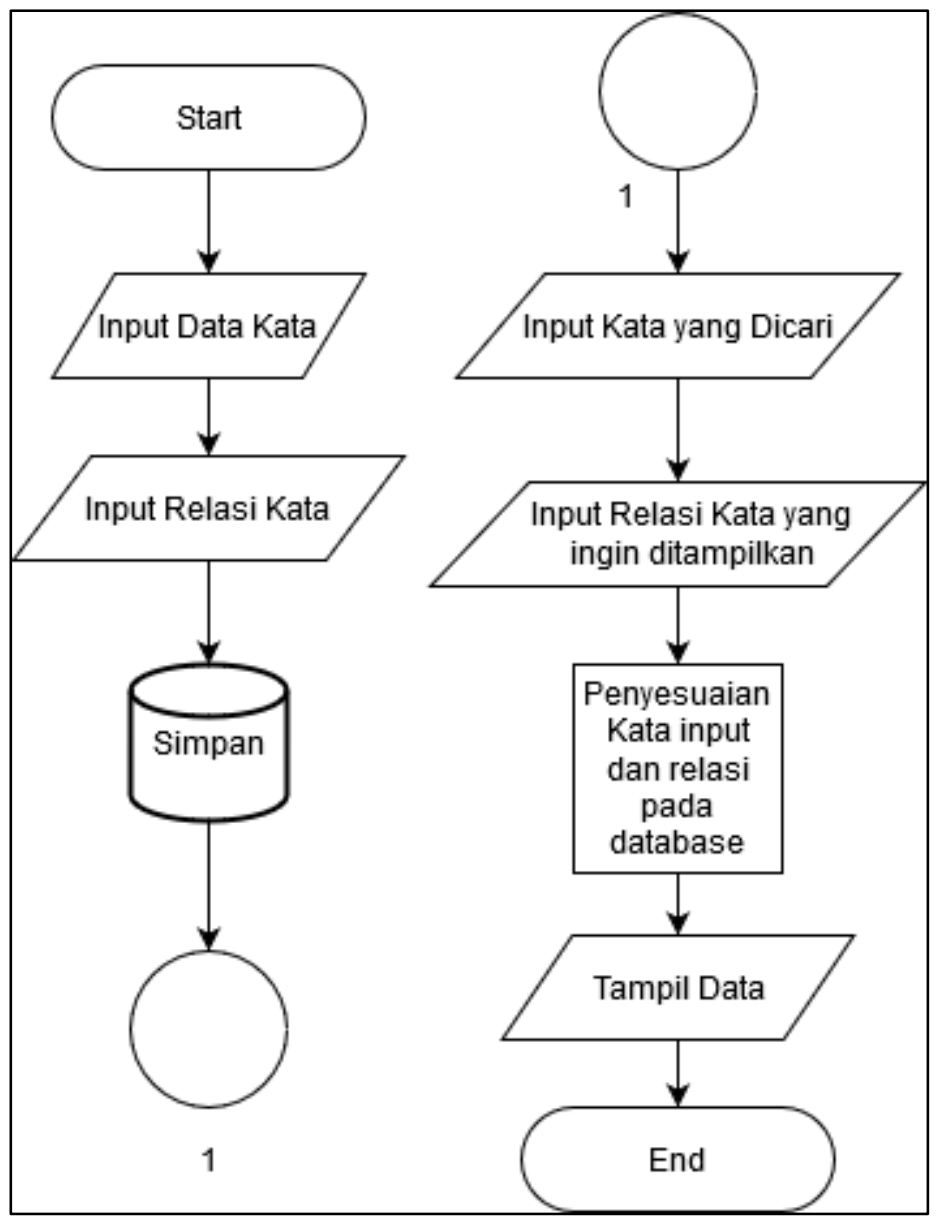

Gambar 2. Proses berjalannya perancangan

Pada tahap perencanaan pengembangan software, software akan dibangung berdasarkan alur yang ditampilkan pada Gambar 2. Pada Gambar 2 menjelaskan bahwa perancangan dimulai dengan menginputkan data kata. Data kata adalah perbendaharaan kata yang telah dipilah. Setelah menginputkan data kata, maka diinputkan relasi antar kata. Relasi antar kata akan berupa relasi yang menghubungkan antara 2 kata dengan ikatan khusus seperti Sinonim, Antonim, Imbuhan, dan KataDasar. Setelah kata data diinputkan di database, maka user bisa memanggil kata di software, yang mana user perlu menginputkan kata dan relasi dari kata yang ingin dicari. Setelah program menyesuaikan kata dan relasi dari user dengan kata dan relasi dari database, maka software akan menampilkan DataKata sesuai keinginan user.

\section{Analisis}

Pada tahap ini, dilakukan pengumpulan data sistem secara keseluruhan dari user melalui observasi atau studi literatur untuk menghasilkan sistem yang diharapkan oleh user. Selanjutnya hasil analisis akan diubah menjadi bahasa pemrograman yang dipahami oleh komputer.

\section{Perancangan}

Tahapan perancangan mentranslasi kebutuhan perangkat lunak dari tahap analisis kebutuhan ke representasi desain agar dapat diimplementasikan menjadi program pada tahap 
selanjutnya.[10] Dengan perancangan diagram alur program, database, pengkodean, dan desain sistem yang mudah untuk dipahami user.

\section{Mengelompokkan kata}

Memilah kata merupakan tahap pertama dalam perancangan WordNet. Perbendaharaan kata dikumpulkan dari KBBI dan Tesaurus Bahasa Indonesia. Proses ini dipilah berdasarkan nama kata, jenis kata, arti kata, sinonim kata, jenis sinonim kata, arti sinonim kata, antonim kata, jenis antonim kata, arti antonim kata, imbuhan kata, arti imbuhan kata. Dari pengelompokan kata berdasarkan atribut tersebut akan membentuk sebuah kata yang saling berhubungan antara kata satu dengan kata yang lainnya. Dalam pemilahan, setiap kata diberikan kode agar tidak terjadi double-input. Sebagai contoh pengelompokan kata akan ditampilkan pada Tabel 1, Tabel 2, Tabel 3, dan Tabel 4:

Tabel 1. Kata acuan

\begin{tabular}{|c|c|c|c|}
\hline Code & POS & Words & \multicolumn{1}{c|}{ Meaning } \\
\hline 001 & $\mathrm{~V}$ & Simpan & $\begin{array}{l}\text { menaruh di tempat yg } \\
\text { aman supaya jangan } \\
\text { rusak, hilang }\end{array}$ \\
\hline
\end{tabular}

Tabel 2. Sinonim dari kata acuan

\begin{tabular}{|c|c|c|c|}
\hline Code Syns & Syns & POS Syns & Meaning Syns \\
\hline 002 & Ringkas & $\mathrm{V}$ & $\begin{array}{l}\text { menjadikan ringkas } \\
\text { (tidak banyak } \\
\text { memerlukan tempat) }\end{array}$ \\
\hline 003 & Tabung & V & $\begin{array}{l}\text { memasukkan uang } \\
\text { sebagai uang simpanan }\end{array}$ \\
\hline 004 & Cadang & $\mathrm{V}$ & $\begin{array}{l}\text { menjadikan } \\
\text { (menyimpan) sesuatu } \\
\text { sebagai persediaan } \\
\text { untuk suatu keperluan } \\
\text { (yang akan dipakai } \\
\text { apabila diperlukan saja) }\end{array}$ \\
\hline
\end{tabular}

Tabel 3. Antonim dari kata acuan

\begin{tabular}{|c|c|c|c|}
\hline Code Ants & Ants & POS Ants & Meaning Ants \\
\hline 005 & Ambil & V & Pegang untuk dibawa \\
\hline
\end{tabular}

Tabel 4. Imbuhan dari kata acuan

\begin{tabular}{|c|c|c|c|}
\hline Code Imbuhan & Imbuhan & POS Imbuhan & Meaning Imbuhan \\
\hline 006 & Penyimpan & $\mathrm{N}$ & Orang yg menyimpan \\
\hline 007 & Menyimpan & $\mathrm{V}$ & mengemasi \\
\hline 008 & Bersimpan & $\mathrm{V}$ & $\begin{array}{l}\text { berkemas (meringkas, } \\
\text { membereskan barang } \\
\text { dagangan, pakaian yg } \\
\text { akan dibawa bepergian) }\end{array}$ \\
\hline
\end{tabular}




\begin{tabular}{|l|l|l|l|}
\hline 009 & Tersimpan & $\mathrm{V}$ & $\begin{array}{l}\text { sudah ditaruh di tempat } \\
\text { yang aman }\end{array}$ \\
\hline
\end{tabular}

\section{Input Kata}

Perbendaharaan kata yang telah dipilah, direpresentasikan menggunakan node yang ditanamkan properti nama kata, arti kata, dan jenis kata. Sehingga, akan membentuk skema node seperti yang ditampilkan pada Gambar 2 .

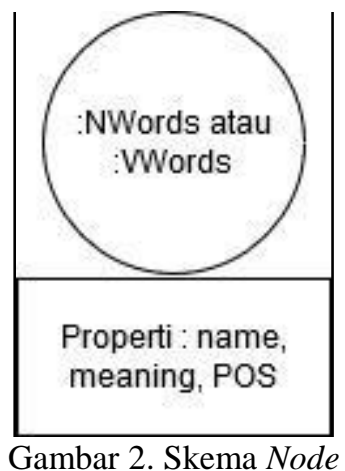

Neo4J memberikan kemudahan dalam meng-entry-kan data ke dalam basis data, yakni dengan menggunakan Cypher. Cypher adalah bahasa query Graph Database yang ekspresif (namun ringkas).[8] Sehingga, penggunaan klausa cypher yakni CREATE mempunyai peran yang sangat besar. Contoh pembuatan node sebagai perwakilan untuk seluruh perbendaharaan kata adalah sebagai berikut :

CREATE (Ambil :VWords\{name : “Ambil”, meaning : "Pegang untuk dibawa”, POS : "Verba"\})

\section{Hubungkan Kata}

Node yang telah dimasukkan di dalam database diberikan sebuah relasi antara satu dengan yang lainnya. Pemberian relasi setiap node dapat menggunakan cypher. Pemberian relasi dilakukan secara berurutan sesuai dengan hasil pemilahan kata seperti yang ditampilkan pada Tabel 1, Tabel 2, Tabel 3, dan Tabel 4. Relasi setiap node dibagi menjadi 4 macam. Setiap relasi akan divisualisasikan dengan warna garis yang berbeda-beda pula. Macam-macam relasi antara lain yaitu Sinonim, Antonim, Imbuhan, dan KataDasar. Sehingga, akan terbentuk skema yang ditampilkan oleh Gambar 5.

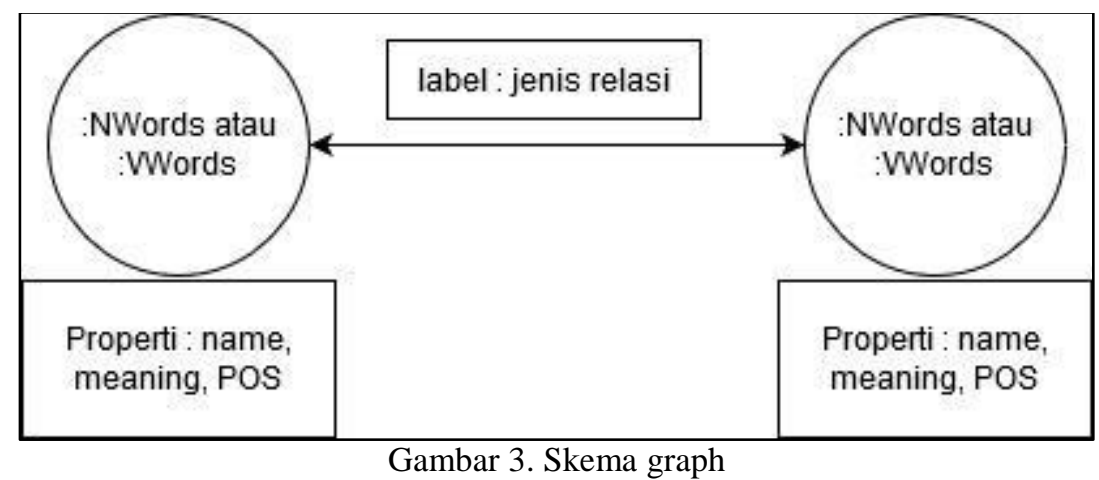

Berdasarkan Gambar 3 maka dibuat contoh yang dapat mewakili setiap proses pembuatan relasi setiap node di dalam database sebagai berikut : 
MATCH(Ambil :VWords), (Simpan :VWords) WHERE Ambil.name = "Ambil" and Simpan.name $=$ "Simpan"

CREATE (Ambil)-[:Antonim]->(Simpan)

CREATE (Simpan)-[:Antonim]->(Ambil)

RETURN Ambil, Simpan

\section{Uji coba}

Proses uji coba database setelah setiap node direlasikan adalah pengujian tingkat kemiripan kata yang terdapat di dalam database. Uji coba akan dilakukan di dalam Neo4J dengan menjalankan cypher query. Cypher query adalah bahasa Graph Database yang mempunyai sifat ekspresif namun ringkas. Proses uji coba ini akan menguji dalam pencarian dan memvisualisasikan seluruh jarak terdekat antara 2 kata, menampilkan setiap kata yang berelasi dengan kata kunci, dan pencarian kata berdasarkan relasi dengan kata kunci.

\section{Mencari dan memvisualisasikan seluruh jarak terdekat antara 2 kata}

Uji coba dalam database dimulai dengan mencoba mencari dan memvisualisasikan seluruh jarak terdekat antara 2 kata. Sebagai contoh untuk mewakili keseluruhan pencarian jarak dapat dilakukan dengan cypher query sebagai berikut :

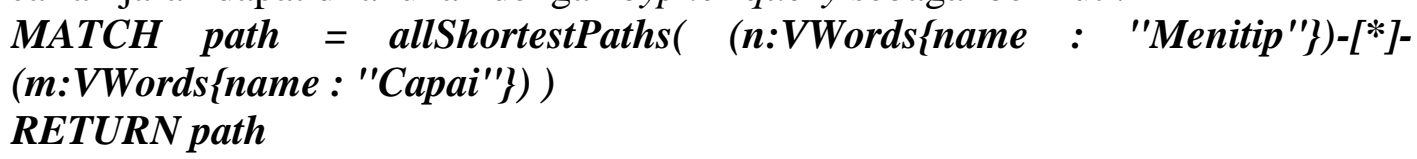

\section{Menampilkan setiap kata yang berelasi dengan kata kunci}

Uji coba ini bertujuan untuk menampilkan list nama setiap kata yang mempunyai relasi dengan kata kunci. Cypher yang digunakan adalah sebagai berikut :

\section{MATCH (x:VWords)-[relatedTo]-(y:VWords \{name: "Simpan"\}) RETURN x.name, Type(relatedTo), y.name}

\section{Pencarian kata berdasarkan relasi dengan kata kunci}

Uji coba ini bertujuan untuk menampilkan perbendaharaan kata yang mempunyai relasi tertentu terhadap kata kunci. Cypher yang digunakan adalah sebagai berikut :

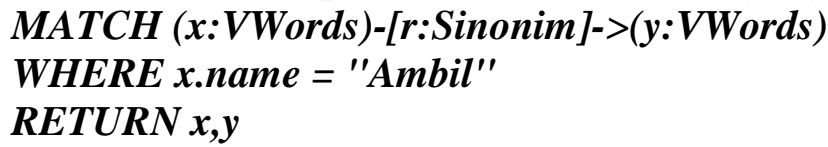

\section{Implementasi}

Pada tahap ini, pengujian fokus pada perangkat lunak secara dari segi logik dan fungsional serta memastikan bahwa semua bagian sudah teruji.[10] Sehingga menghasilkan sistem yang sesuai dengan kebutuhan $u$ ser.

\section{Implementasi dalam bentuk aplikasi}

Pada tahap setelah uji coba database, maka dirancang sebuah aplikasi sederhana dengan menggunakan Bahasa Pemrograman Java yang didukung dengan IDE Netbeans 8.2. Proses menghubungkan dengan database menggunakan Java Driver 1.7.2. Aplikasi ini akan mempunyai alur berjalan yang akan ditampilkan pada Gambar 4.

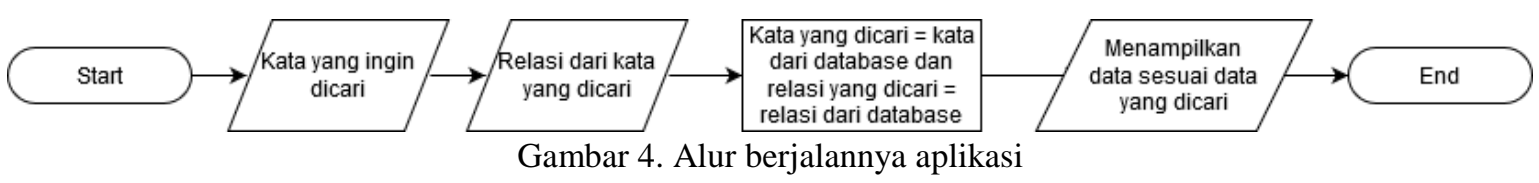




\section{HASIL DAN PEMBAHASAN}

\section{Hasil Entry Database}

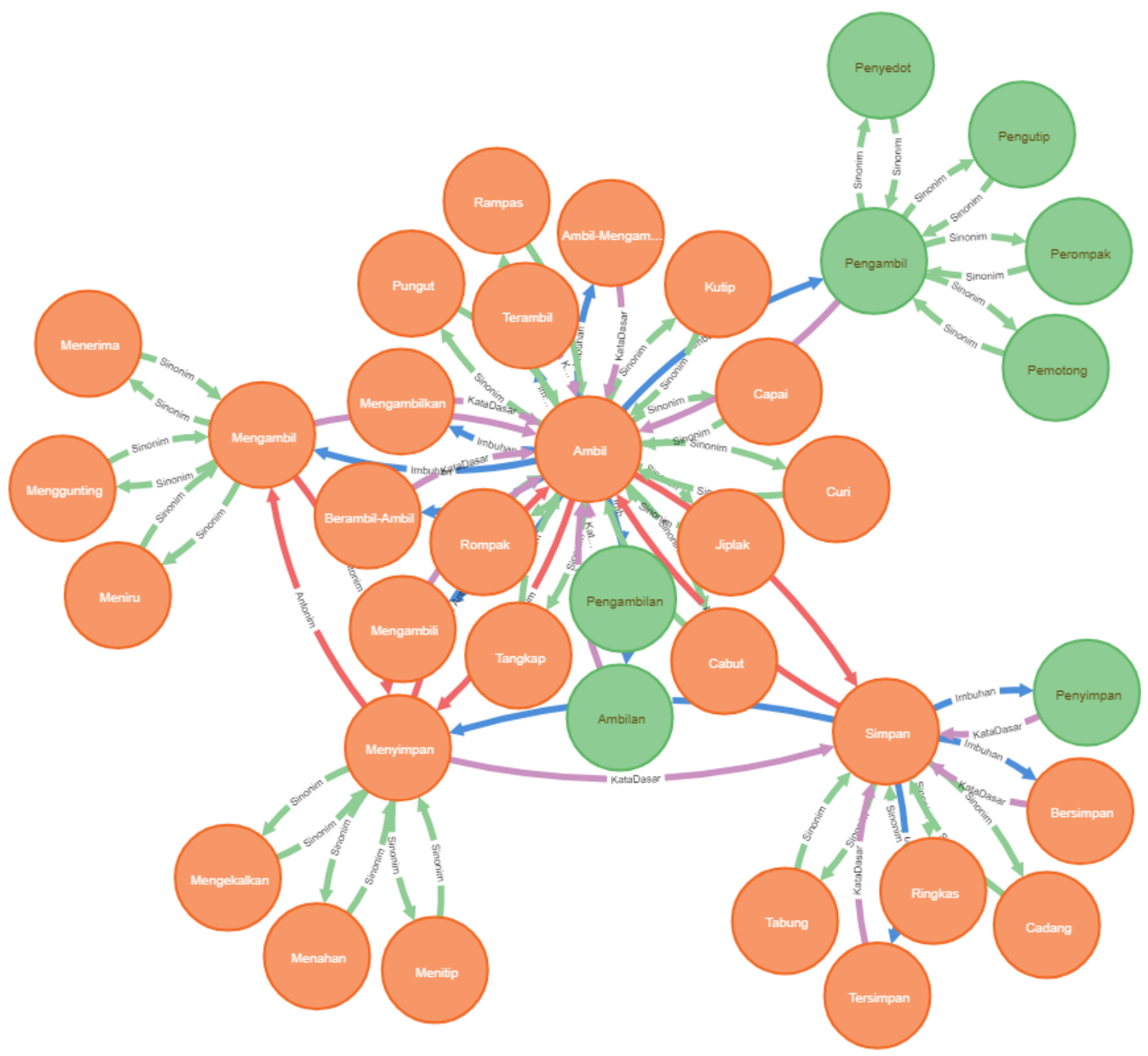

Gambar 5. Visualisasi data di dalam database

Data yang di-entry-kan akan ditampilkan menjadi bentuk graph seperti gambar 5. Node berwarna oranye memvisualisasikan bahwa kata tersebut adalah kata verba, sedangkan node yang berwarna hijau memvisualisasikan bahwa kata tersebut merupakan kata nomina. Sehingga akan tampak dengan jelas perbedaan dari kedua jenis kata tersebut. Setiap node dihubungkan dengan garis penghubung dengan warna yang berbeda. Garis berwarna biru menandakan Imbuhan, garis berwarna hijau menandakan Sinonim, garis warna ungu menandakan KataDasar, dan garis warna merah menandakan Antonim. Hubungan setiap node berprinsip bolak-balik. Sehingga, setiap node mempunyai sifat yang saling berelasi dengan node yang lain.

\section{Hasil Uji Coba}

\section{Mencari dan memvisualisasikan seluruh jarak terdekat antara 2 kata}

Setelah hasil visualisasi data sudah sesuai. Data diuji coba dengan memasukkan Cypher untuk mencari jarak terdekat antara 2 node. Berikut adalah hasil dari pencarian jalur terdekat : 


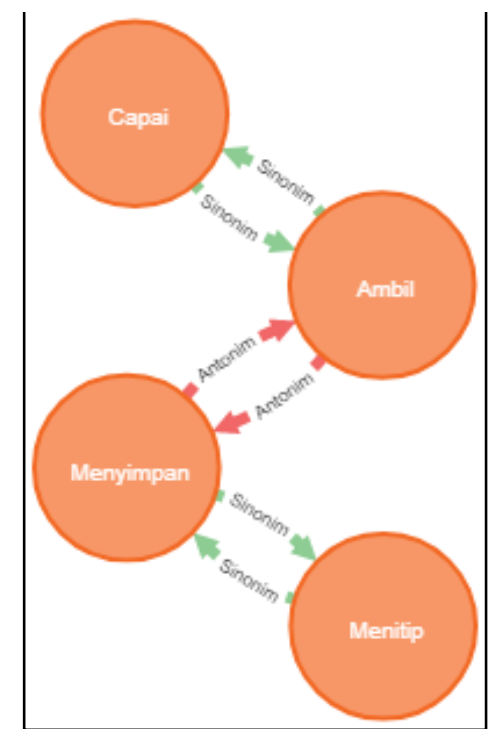

Gambar 6. Hasil uji pencarian jarak terdekat antara 2 kata

Gambar 6 menampilkan hasil dari visualisasi pencarian jarak terdekat dari tujuan awal adalah kata "Capai" hingga menuju kata "Menitip".

\section{Menampilkan setiap kata yang berelasi dengan kata kunci}

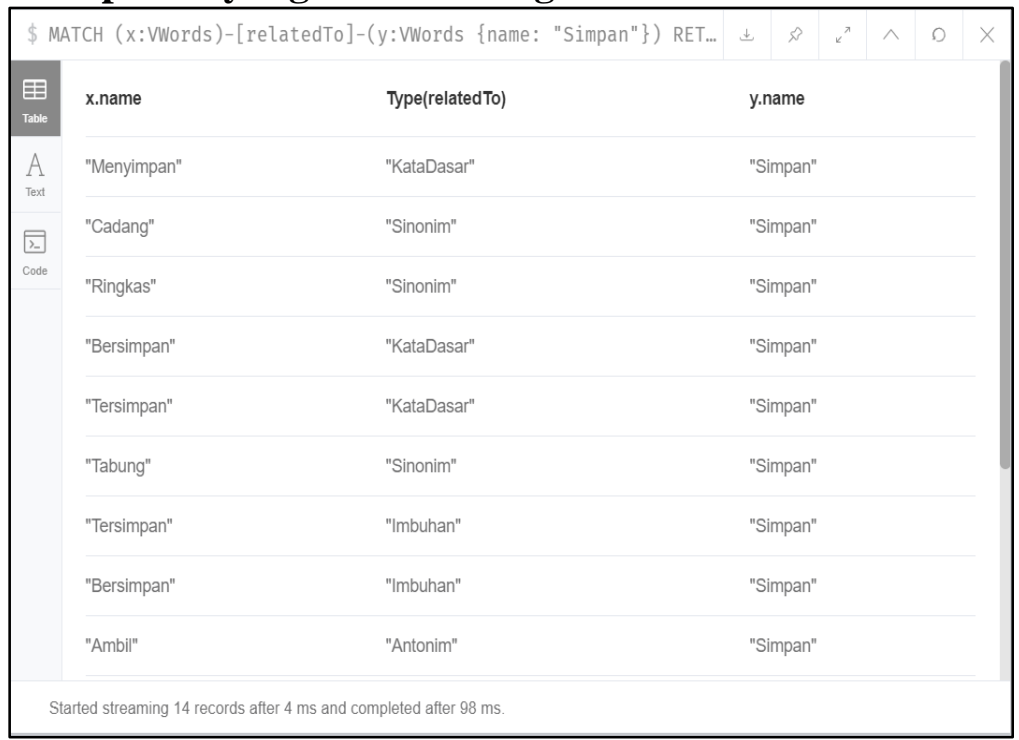

Gambar 7. Hasil uji penampilan setiap kata yang berelasi dengan kata kunci

Proses menampilkan kata yang berelasi dengan kata kunci mempunyai hasil yang akan ditampilkan pada Gambar 7. Pada gambar tersebut menjelaskan bahwa terdapat setiap kata yang saling berkaitan dengan kata kunci dengan relasi yang bermacam - macam. Daftar kata dalam uji coba ini akan dilanjutkan ke dalam implementasi aplikasi untuk menampilkan setiap kata yang berelasi.

\section{Pencarian kata berdasarkan relasi dengan kata kunci}

Setelah hasil visualisasi data sudah sesuai. Data diuji coba dengan memasukkan Cypher untuk pencarian berdasarkan relasi yang diberikan pada setiap node. Berikut adalah hasil pencarian kata menggunakan kata kunci yang sama, tetapi berdasarkan relasi yang berbeda. 


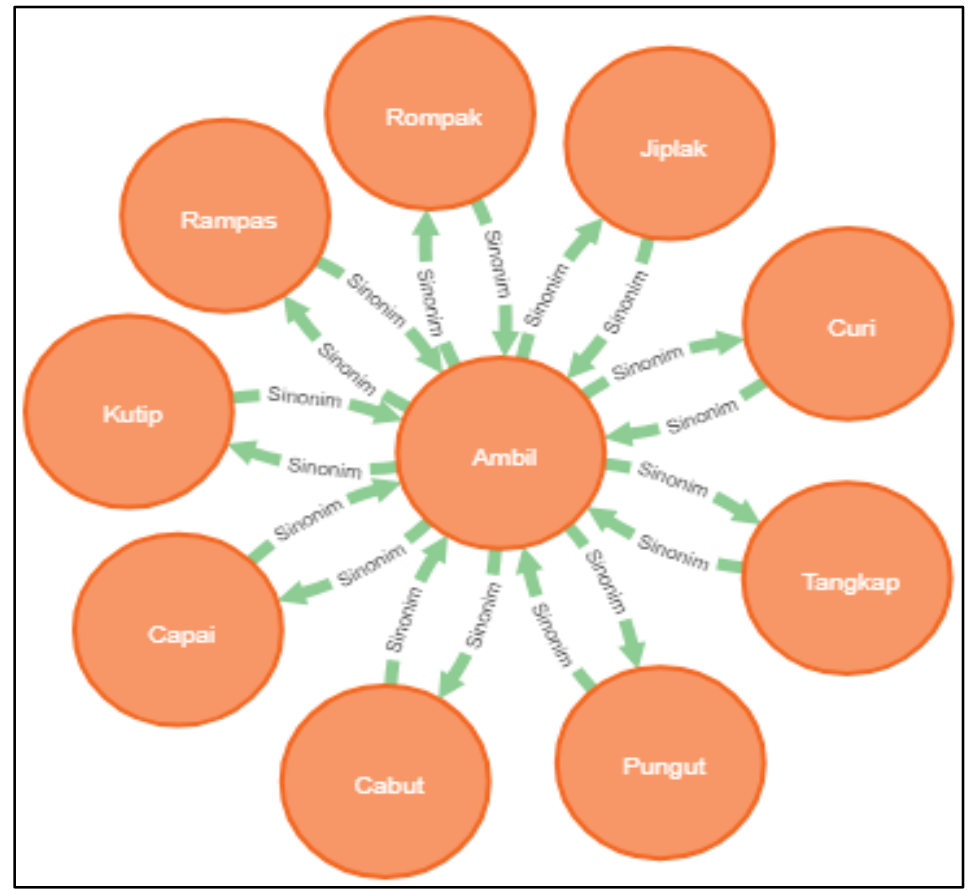

Gambar 8. Hasil uji pencarian berdasarkan Sinonim kata

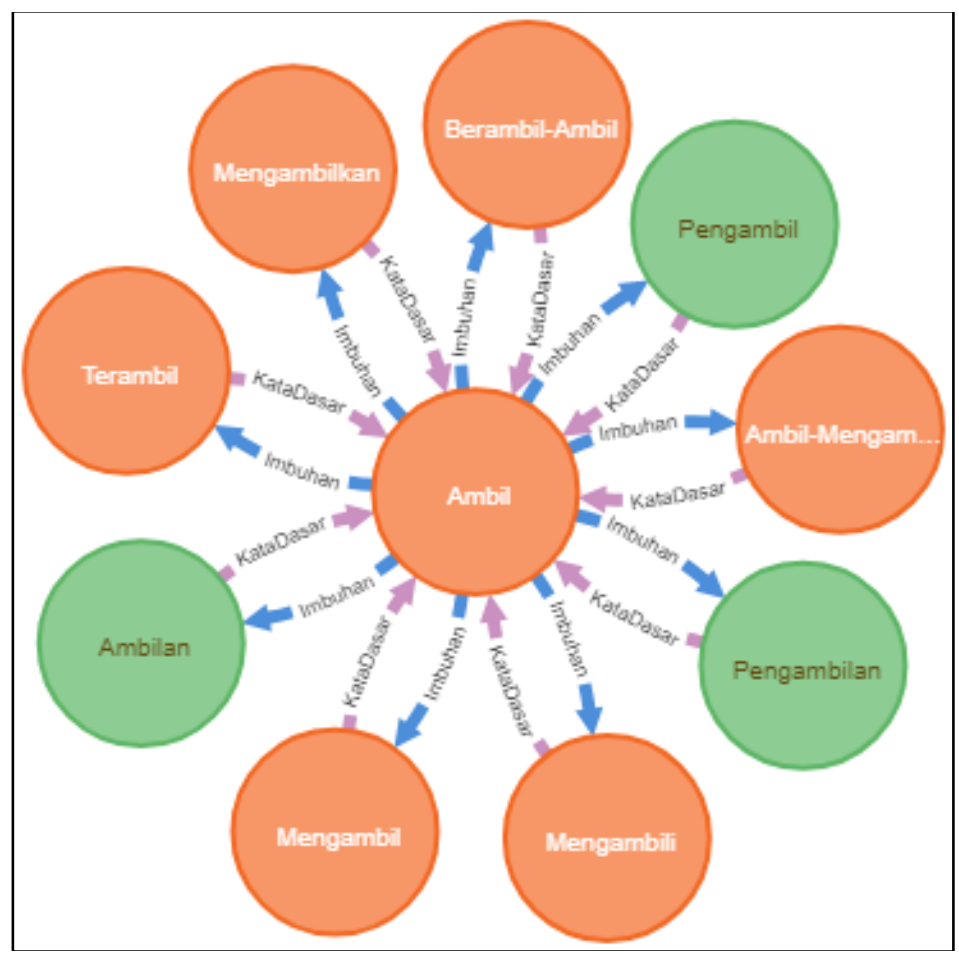

Gambar 9. Hasil uji pencarian berdasarkan Imbuhan

Gambar 8 dan Gambar 9 memberikan hasil visualisasi pencarian sebuah kata dengan kata kunci "Ambil". Gambar 8 memvisualisasikan hasil perbendaharaan kata yang berdasarkan relasi Sinonim kata. Sedangkan, pada Gambar 9 memvisualisasikan hasil perbendaharaan kata yang berdasarkan relasi Imbuhan kata. 


\section{Hasil Implementasi dalam bentuk aplikasi}

Perancangan aplikasi sederhana menggunakan alur yang ditampilkan pada gambar 4 mempunyai hasil yang ditunjukkan pada gambar 8 . Berikut adalah desain pada software tersebut :

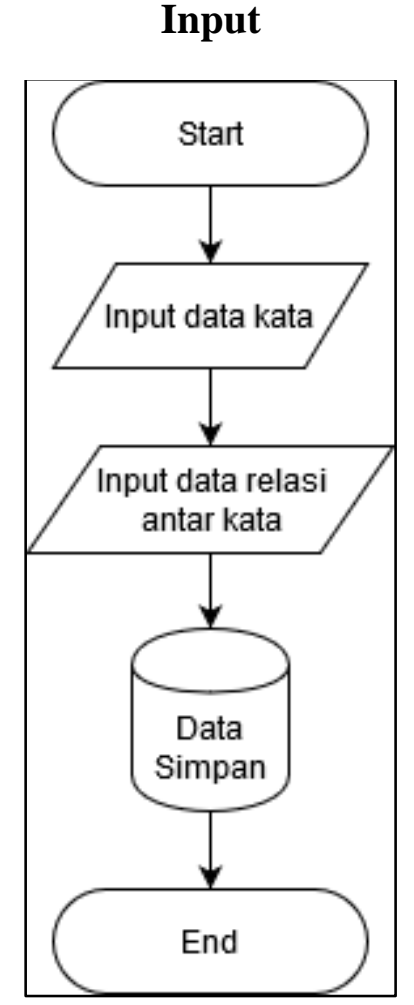

Gambar 10a.
Process

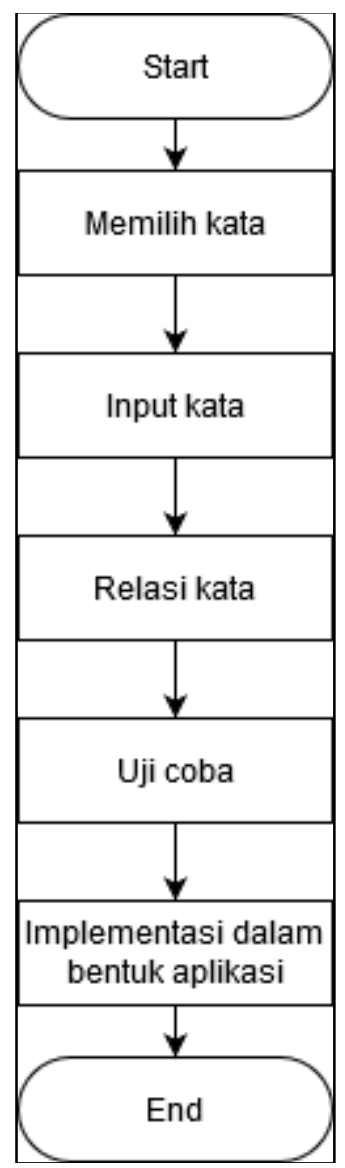

Gambar 10b.
Output

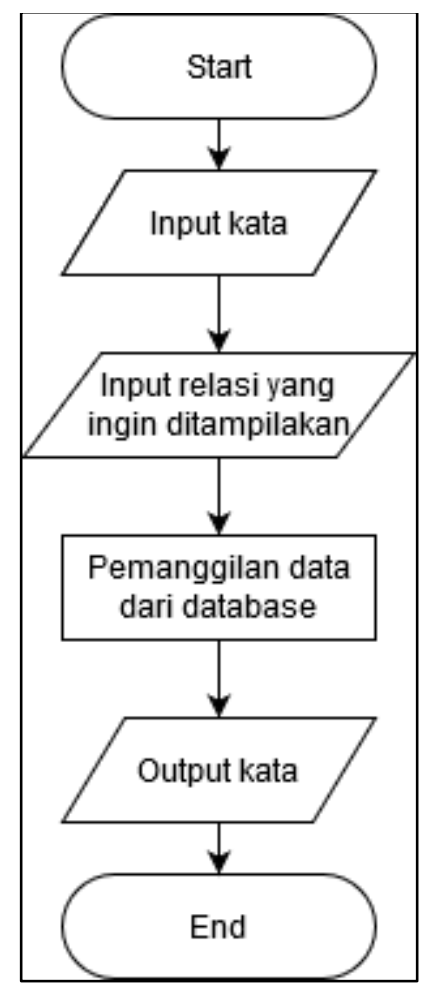

Gambar 10c.

Gambar 10. Desain perancangan aplikasi

Hasil implementasi yang telah ditampilkan pada gambar 10 menjelaskan tentang desain dari perancangan aplikasi. Gambar 10a menjelaskan tentang proses input, gambar 10b menjelaskan tentang process, gambar 10c menjelaskan tentang proses output.

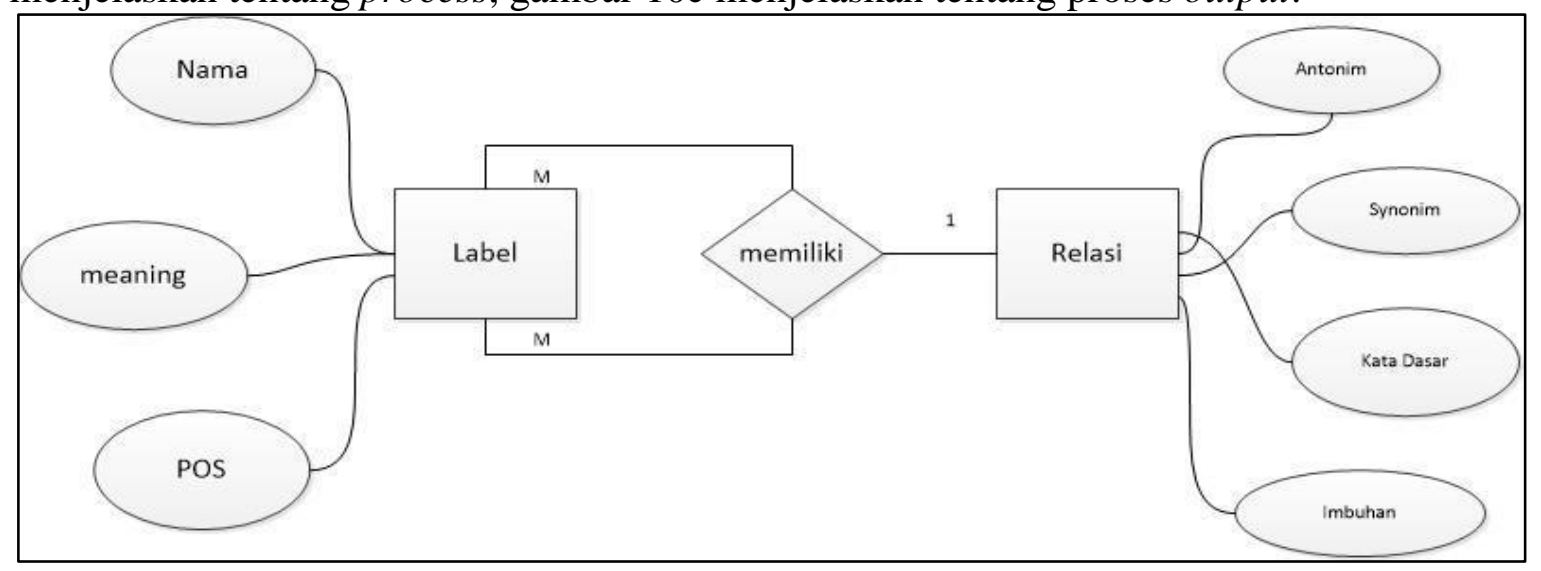

Gambar 11. Desain ERD graph database 
Visualisasi software dari desain tersebut adalah sebagai berikut:

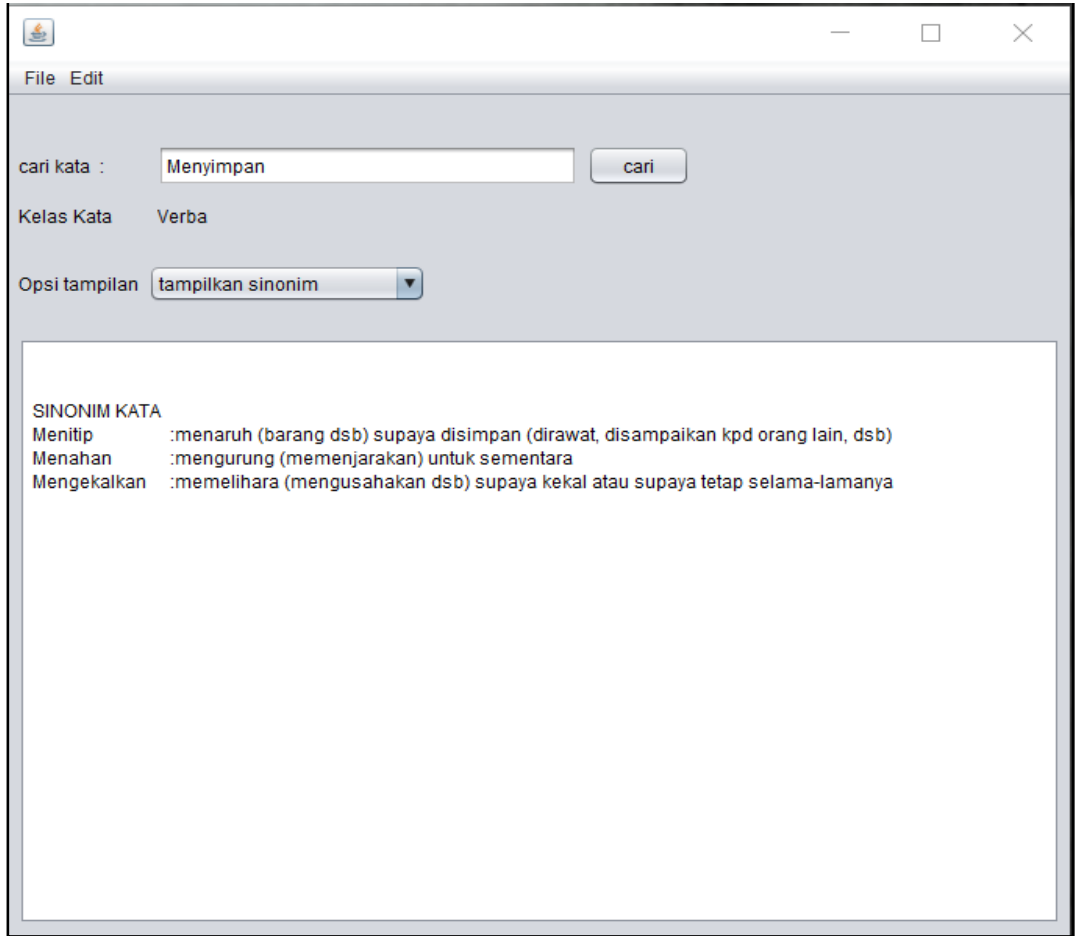

Gambar 12. Hasil Implementasi di Aplikasi

Gambar 11 menunjukan elemen-elemen pada database. Sedangkan pada gambar 12 menampilkan hasil dari uji coba dalam menampilkan perbendaharaan kata yang berdasarkan Sinonim dari kata kunci "Menyimpan". Hal ini menunjukkan bahwa hasil yang diperoleh yaitu memuaskan dan data yang ditampilkan sesuai dengan yang ada di database.

\section{KESIMPULAN}

Berdasarkan hasil uji yang telah dilakukan dapat disimpulkan bahwa penggunaan Graph Database dalam perancangan WordNet memiliki tingkat fleksibilitas yang baik. Relasi setiap node dapat dirubah atau di-update tanpa merusak atribut yang tertanam di dalam node. Visualisasi perbendaharaan kata dalam database lebih mudah dipahami untuk analisa relasi antar-kata karena setiap kata divisualisasikan dengan node dan garis sebagai relasinya yang mempunyai warna berbeda antara satu dengan lainnya. Proses uji coba Neo4J juga menghasilkan hasil akhir yang diharapkan seperti mencari jarak terdekat antar-kata tanpa memandang jenis relasi yang menghubungkan antar node. Selain itu, Neo4J juga memudahkan dalam pengimplementasian database ke dalam pembuatan aplikasi sederhana yang mudah untuk digunakan. Penelitian selanjutnya diharapkan dapat menggunakan hasil dari penelitian ini dalam proses perhitungan similaritas makna kata. Sehingga, aplikasi dapat lebih dikembangkan dengan penambahan fitur hasil similaritas antar kata.

\section{REFERENSI}

[1] K. Batsuren, A. Ganbold, A. Chagnaa, and F. Giunchiglia, "Building The Mongolian WordNet," 2019.

[2] D. J. Restina, M. A. Bijaksana, and K. M. Lhaksmana, "Pembangunan Synonym Set untuk WordNet Bahasa Indonesia dengan Menggunakan Metode Komutatif," Ind. J. Comput., vol. 4, no. 2, pp. 147156, 2019.

[3] K. Nagi, "A New Representation of WordNet ${ }^{\circledR}$ using Graph Databases On-Disk and In-Memory," DBKDA, 2013. 
[4] Gonzalez-Agirre, Aitor et al. "A Graph-Based Method to Improve WordNet Domains." CICLing (2012).

[5] Jain, Amita \& Vij, Sonakshi \& Castillo, Oscar. (2019). Hindi Query Expansion based on Semantic Importance of Hindi WordNet Relations and Fuzzy Graph Connectivity Measures. Computación y Sistemas. 23. 10.13053/cys-23-4-2984.

[6] Arora, Piyush \& Bakliwal, Akshat \& Varma, Vasudeva. (2012). Hindi Subjective Lexicon Generation using WordNet Graph Traversal. Int-1 J. Computational Linguistics and Applications. 3.

[7] G. Miller, R. Beckwith, C. Fellbaum, D. Gross, and K. Miller, "Introduction to WordNet: An On-line Lexical Database*," vol. 3, 1991, doi: 10.1093/ij1/3.4.235.

[8] I. Robinson, J. Webber, and E. Eifrem, Graph Databases. O’Reilly Media, Inc., 2015.

[9] M. Ardani, M. A. Yaqin, and M. H. Suhartono, "Implementasi Graph Database untuk Menentukan Rute Perjalanan Transportasi Umum,” 2019.

[10] Tabrani, Muhamad. "Penerapan Metode Waterfall pada Sistem Informasi Inventori PT. Pangan Sehat Sejahtera." Jurnal Inkofar, vol. 1, no. 2, 2017. 